\title{
Swedish Parent's Experiences of Joint Physical Custody
}

\author{
Åsa Carlsund*, Kennet Asplund, Eva Sellström and Ulrika Eriksson
}

\author{
Department of Health Sciences, Mid Sweden University, Östersund/Sundsvall, Sweden
}

\begin{abstract}
Aim: This study's aim was to learn more about parent experiences, when living in joint physical custody with their children.

Methods: The study design was descriptive, using a qualitative approach. Interviews were conducted with 28 parents who lived in joint physical custody with their children. Content was analysed using inductive content analysis.

Results: Participants with joint custody reported many positive experiences, and a similar process of adapting to the new living- arrangement. Results indicate that shortly after the separation parents were mainly occupied with emotional reactions to the new family situation. After two to three years, or in some cases longer, things seemed to settle down and the participants became more accustomed to the arrangements.

Conclusion: This qualitative study provides insights into parents' experiences of living in joint physical custody with their children. Many positive experiences and a similar process of adapting to the new arrangement were revealed. In the initial period, the parents seemed mainly to have been occupied with emotional reactions to the new family situation.
\end{abstract}

Keywords: Content analysis, experiences, family, joint physical custody, parents, qualitative, well-being.

\section{INTRODUCTION}

Parental separations are currently very common throughout the developed world, and in Sweden, an increasing number of couples with children split-up every year. In 2011, three per cent of all Swedish children with married or cohabiting parents experienced a parental separation. Children with cohabiting parents were more often involved in parental separation, compared to children with married parents [1].

Parental separation creates a new family dynamic, generating a more complex family situation [2-5]. Usually at least one, possibly all members of the household relocate. Family members' roles also change; in turn this might disrupt old family habits and lead to an inconsistent family situation [4, 6-8]. Until recently, separation usually meant that children would live permanently with one of their parents (typically mother) [9, 10]. Most previous findings indicate that separated mothers and fathers report qualitatively different experiences in post separation parenting [11], however there is a great lack of more recent studies on parents' experiences, and those which exist show rather ambiguous results $[12,13]$.

Parents perform a vital role in their children's social, emotional, physical, and economic development, children benefit from regular contact with both parents [2, 3, 14, 15]. Nevertheless, there are numerous of studies reporting evidence of an augmented risk for psychosocial health problems in children living with a single parent [16-18]. Lost

*Address correspondence to this author at the Department of Health Sciences, Mid Sweden University, SE-831 25 Östersund, Sweden;

Tel: +46(0)63165665; Fax: +46(0)63165626;

E-mail: Asa.Carlsund@miun.se contact with the absent parent, usually the father, has been suggested as a possible explanation of these health problems $[7,8,15,19]$. Joint physical custody arrangements following a divorce have emerged as a way to maintain the important relationship between children and their parents [7, 8, 19-21]. This means, children reside in each parent's home for equal periods of time, alternating between homes at regular intervals, for example every other week [22-24].

Approximately $30 \%$ of children whose parents have separated share their housing at least some of the time with each parent $[20,25,26]$. A recently modified Swedish law states that a child has the right to close and well-established contact with both parents [27]. Municipal family counselling and family court are both part of the municipal social services. Family court help in several family matters such as parenting and custody issues. Municipal family counselling provides among other things, support and assistance in relationship matters [27]. Furthermore, parents must have equal opportunity to be involved and share responsibility for the child after a separation [27]. The limited research available indicates that both children and parents are better adjusted in joint physical custody than families in which the child lives permanently with one parent [18, 28, 29]. In a recent study, children in joint physical custody reported health and well-being similar to that of children in twoparent households [30]. Several studies have shown that good support and communication in the family can diminish the negative consequences of the separation process $[4,15$, $19,31]$, and can also be a protective factor for the family members [31-33]. Further, parents with inadequate communication can contribute to emotional insecurity in the children and reduce the quality of the parent-child relationship [7, 19, 31, 33]. Studies also have shown that 
maintaining close relations with both parents can have protective effects on children's health [19, 31, 34, 35].

Earlier studies on family arrangements mostly focus on children's outcomes. We found few recent studies examining joint physical custody, and to our knowledge even fewer have studied the experiences of parents with joint physical custody. The aim of this study was to gain knowledge regarding the parents' experiences of living in joint physical custody with their children.

\section{METHOD}

\section{Design and Sample}

A qualitative descriptive design was used to illustrate parents' experiences of living in joint physical custody with their child/children i.e. in present study every other week. Qualitative studies permit in-depth information; by using the participants' own words you gain knowledge regarding important and specific areas [36]. The participants were recruited from a county in the interior part of northern Sweden, with a population density of approximately one person per sq $\mathrm{km}$. Total county population was 59373 individuals, of which 30500 were women and 28873 were men. The average income among the community inhabitants was lower compared to the entire country (county 253066/national 270286). The county inhabitants were mostly Swedish- born (almost $97 \%$ ). Of the county inhabitants aged 25-64 years, twenty per cent had a three year university education and eleven per cent had a three year senior high-school education.

\section{Procedure}

Potential participants were identified through the student records at five randomly selected schools $(n=1570)$ in a county located in the northern part of Sweden. There were no official county statistics on how children's time was distributed between their two homes. It is therefore possible that although both parents require information from school, their living arrangements may not qualify as joint physical custody, i. e. The children live $50 \%$ of the time with each parent. The parents of children with two home addresses received a written invitation to participate in the study (n: 324). With reference to study limitations, the letter said that the first 35 people to respond would be invited to participate in the study. Thirty-three letters arrived within the specified timeframe. There was a possibility that although both parents required information from school, their living arrangements did not qualify as joint physical custody i.e. in this study living $50 \%$ of the time with their children. Parents who agreed to participate were asked to sign a separate letter of consent and return to the first author before the $10^{\text {th }}$ of March 2012. Then the parents interested in participating were contacted, to arrange the location and time for the interview. Since the intention was to obtain individual experiences of living in joint physical custody, all interviews were performed without finding out if the former partner were attending to the study.

\section{Participants}

The inclusion criteria for participation in the study were that parents should have a child or children aged between 11 and 15 years with whom they had been living in joint physical custody every other week for at least one year. The participating parent and the child should also live within the county and speak Swedish.

It is possible that some participants were former partners, but we had no access to that information. If that were the case, some participants might have been unwilling to open up entirely because of a fear that their information would not be treated confidentially. In an effort to avoid this possibility, the participants were thoroughly informed about the confidentiality guarantee, voluntary participation, and their right to discontinue at any time.

Thirty-three individuals matched the criteria and agreed to participate. Five individuals subsequently declined participation because of time limitations or illness. In all, 28 interviews were conducted; 10 of the participants were men, and 18 were women. The mean age of the participants was 44 years. The participants were a parent of one or two children, approximately half of them were in a new relation. The approximate distance to the other parent, was between 200 meters and $6000 \mathrm{~km}$. Time since divorce were between two and fourteen years, mean 6.6 years.

\section{Data Collection}

All of the interviews except three were conducted in a meeting room at the first authors' workplace (the remaining three were conducted at the home of the participant). Individual interviews were conducted based on one openended question: "Would you please describe your experience of living in joint physical custody with your child/children?" If clarification was needed, follow-up questions like "Can you tell me more about $\mathrm{xxx}$ " or "Can you further explain your thoughts about xxx" were asked. The interviews were tape-recorded and lasted 30 to 90 minutes (average: 50 minutes).

\section{Qualitative Content Analysis}

The recordings were listened to several times before transcribing them. The transcribing was completed verbatim shortly after listening to the recordings. The texts were then diligently worked through step by step, using qualitative content analysis [37]. To grasp a sense of the whole, the entire text of the transcribed interviews was read through several times. In order to structure the data and identify meaning units, notes were made in the text. Meaning units consists of one or several sentences related to each other through their content, guided by the aim of the study [36]. Each meaning unit was condensed and labelled with a code. The codes were compared based on similarities and differences until four subthemes were gathered, the subthemes were formulated into a theme, presented in Fig. (1) $[36,37]$. All authors were involved in the various stages of the analysis. The analysis process is not linear, the process implies moving back and forward between the steps, in order to move towards a greater abstraction. An example of the analysis process is presented in Table $\mathbf{1}$.

\section{ETHICAL CONSIDERATIONS}

Verbal and written information was given to the participants before being included in the study. They were informed that confidentiality was guaranteed, that participation was voluntary, and that they had the right to 


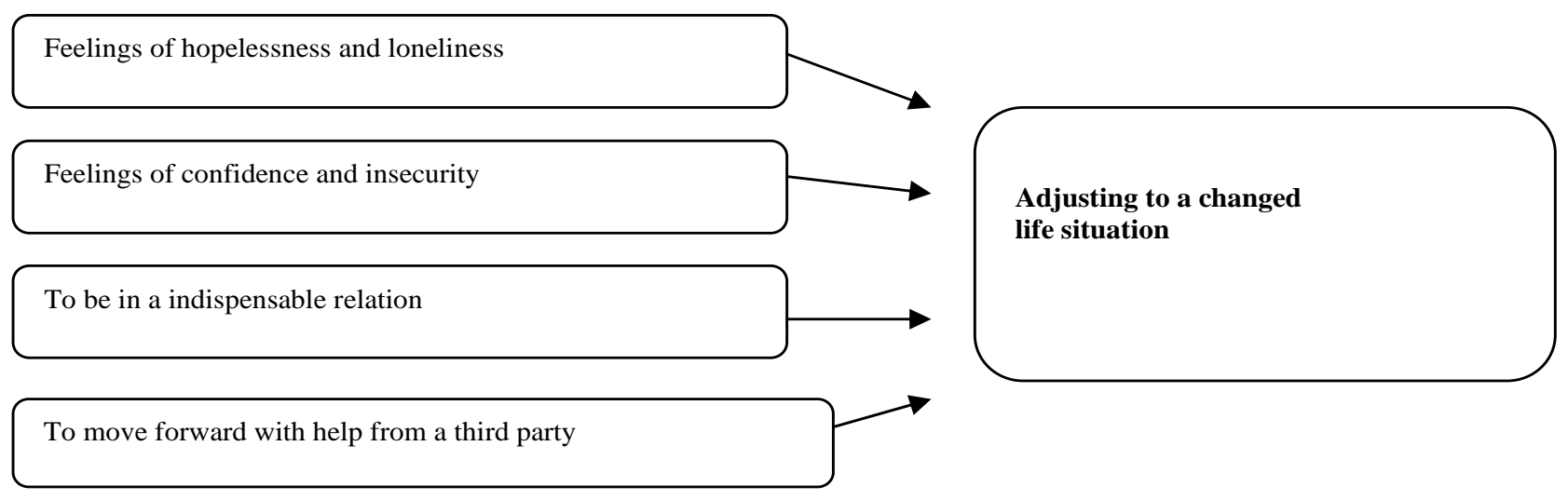

Fig. (1). The sub- themes and the theme that emerged during the analysis process.

Table1. A reprehensive example of the abstraction process.

\begin{tabular}{|c|c|c|c|c|}
\hline Meaning Unit & Condensed Meaning Unit & Code & Subtheme & Theme \\
\hline $\begin{array}{l}\text {...of course- in the beginning it was very hard not to see the children } \\
\text { every day... an empty quiet apartment, no shoes in the hallway and no } \\
\text { happiness inside... How ever, you were just forced to adapt to the new } \\
\text { situation }\end{array}$ & $\begin{array}{l}\text { In the beginning- } \\
\text { Emotionally very hard not } \\
\text { to see the children }\end{array}$ & $\begin{array}{l}\text { Tumultuous } \\
\text { emotions }\end{array}$ & $\begin{array}{l}\text { Feelings of } \\
\text { hopelessness } \\
\text { and loneliness }\end{array}$ & $\begin{array}{l}\text { Adjusting to } \\
\text { a changed } \\
\text { life situation }\end{array}$ \\
\hline $\begin{array}{l}\text { Yeah, we have lived in shared physical custody - let's see, I'm trying to } \\
\text { figure it out - since } 2005 \text {, when we separated. And in the beginning, of } \\
\text { course, it was very hard, to realize that you somehow couldn't see your } \\
\text { child every day, as you used to... }\end{array}$ & $\begin{array}{l}\text { Realizing that you couldn't } \\
\text { see your child every day } \\
\text { was very hard. }\end{array}$ & $\begin{array}{l}\text { Tumultuous } \\
\text { emotions }\end{array}$ & $\begin{array}{l}\text { Feelings of } \\
\text { hopelessness } \\
\text { and loneliness }\end{array}$ & $\begin{array}{l}\text { Adjusting to } \\
\text { a changed } \\
\text { life situation }\end{array}$ \\
\hline
\end{tabular}

discontinue the interview at any time [38]. The authors' contact information was provided in case the interview caused the participants need for support. The regional Research Ethics Committee of Umeå reviewed and approved the study (2011-425-31Ö).

\section{RESULTS}

The inductive content analysis of the interviews with parents who lived in joint custody with their children (11 to 15 years old) revealed that, the parents' shared many similar experiences. In the process of adapting to the new arrangement the participant's shared comparable experiences.

At first the parents mainly were occupied with emotional reactions to the new family situation. After two to three years, or longer, the participants became more accustomed to the joint custody arrangement. The results are presented in four sub- themes and one theme.

\section{Adjusting to a Changed Life Situation}

A theme "Adjusting to a changed life situation" was formulated in the process of data. During the content analysis four sub-themes were revealed: "Feelings of hopelessness and loneliness", "Feelings of insecurity and confidence", "To be in an indispensable relation" and "To move forward with help from a third party".

\section{Feelings of Hopelessness and Loneliness}

The first period of joint physical custody was expressed as a shock, terribly tough with tumultuous emotions. Bodily pain, feelings of sadness, disappointment and lack of control were also described. An accusatory attitude towards themselves was revealed, considering what they exposed to their children.

I was scared to death in the beginning, because I thought I would die if I couldn't see them every week (5)

... the most important part of his life - one of the most important - that his life has been so divided, will it affect him? Maybe (sigh) That's what you are worried about, of course! Have I done this to him? If his life goes to hell, I will never forgive myself (1)

Feelings of loneliness, emptiness, and thoughts about losing half of the child upbringing were exposed. They also expressed how hard it was not to spend time with, and be physically close to, their children every day. Missing ordinary matters such as, a hug, bedtime routines, homework, and dinner together or watching TV.

You want nothing more than to have them with you all the time. But, now your situation turned out this way, so you have to take advantage of the time you do have. But the children are torn apart, so I can't enjoy my perfect world, so to say... So ... so that's the way it is (9)

This enormous loneliness that comes up; that was hard in the beginning. No children, no 
relationship, no nothing (...). It was very lonely (26)

Difficulties to relax and enjoy life when their children were not with them were reported, a constant craving for having their children nearby. The interviewer was ensured that they valued the time they spent with their children, compared to before the separation. The sound of the children's presence in the apartment or house, a cup of tea together or sitting next to each other in the sofa were examples of things higher valued. Sadness regarding missing parts of their children's everyday activities and a strange feeling of betraying their children was expressed, as if shirking their responsibility even though the children were being cared for by the other parent. Parents with difficulties in finding their bearings without their children were forced to handle the situation, and find ways to keep active by themselves, with friends, a new partner, or by working extra hours.

\section{I can't understand 'time on my own'. That argument is very, very strange and a foolish argument. 'It's nice to spend some time alone'. That's certainly not why I became a father.... That's because I like children (6)}

Anger and bitterness were revealed. Mainly concerning how the situation of joint physical custody had been solved. Anger over how the former partner failed in leaving and retrieving routines that already were made up, ignored helping out in financing new skates, skies or computer for the child. Bitterness over how the family life turned out to be, with separation instead of happily ever after. Bitterness of how the former partner went on with life, without any thought of how it would affect the former family.

If the kids want to know, I just tell them, 'ask Daddy, because he was the one who wanted to divorce (8)

Approximately one fourth of the parents initially resisted joint physical custody, but was forced to cope, while the others considered it a matter of course. The former partners late working hours, financial problems, age of children, and long distance to school, friends or the other parent were arguments raised against joint physical custody. Children need both their parents, different parents are useful in different ways was the most common argument for considering joint physical custody as a matter of course.

I hoped that they would only want to live at my place; that they would say, 'I only want to live with you'. But you must sort of try to let go of your own ego and think about what's best for the children (3)

For me it was natural that I would want to have an active role in the children's upbringing, and that's what their mother wanted too, of course! (26)

The nuclear family was described as the ideal family, weather the separation occurred two or ten years ago. Even though the participants knew that separations become more and more common, feelings of failure and distrust were exposed.
A nuclear family is of course the ideal, but that's not the way it is for many families today. The children ought to have both their parents... that's what's best for them... (4)

\section{Feelings of Insecurity and Confidence}

Low self confidence and insecurity were described when the children exposed desire to be close to the absent parent feelings of insecurity and fear of doing harm to the child were revealed. The actual move between parents were exposed as a time- consuming but necessary event, the packing and unpacking, were described as quite unsettling, even though the distance between the two homes wasn't geographically very far. Also in this case feelings of insecurity of doing harm to the child were exposed.

She told me she felt like a 'thing' being moved around, although the distance was not so far in our case. But she felt bad about it, in the beginning anyway (25)

Under the circumstances, satisfaction with the present solution of joint physical custody was described, and they spoke warmly about children's closeness, safety, and trust in both their parents. The parents gave detailed descriptions of different solutions that made the joint physical custody solution work in their case e.g. living nearby allows the children to feel physically close to both parents. Talking to each other in a grown up way, and avoiding own anger and bitterness with focus on the best solution for the child were revealed.

Sometimes I have to bite my tongue .... I think he is a great dad ... but he is not good with money. But that is not my business any more, lucky me! ... As long as he takes his father respons... I cannot, and will not argue with him. (27)

At first the transitions between homes were described as challenging practically as well as emotionally, with packing and unpacking of clothes, teddy bears, diapers and stroller for example. When the children grew older, and were able to choose when or how to move between parents, the entire family were described as considerably less affected by the transitions compared to in the beginning of joint physical custody.

They are rather grown up now.... And now they think it's all right. Sometimes they think it's a bore to pack and unpack their bags, and that it's hard to keep track of their stuff (8)

If you are honest and talk to the children, they can feel okay about the situation. You can communicate with small children as well, like, from now on it's going to be like this, how do you feel about it? At least try to explain. It's hard, but you owe it to them (8)

Confidence in their future relationship with their children was illustrated, great hope of seeing them more, or at least as much as currently. Whether there had been two or ten years since the separation descriptions of hope that their children would chose to live full-time at their house in the future was 
described. Nevertheless satisfaction with the current arrangement was also presented.

I try not to think so much about the future, how it's going to be, eh. Now I have a kind of they are, so to say - when they sort of, they kind of call it 'at home' or 'at Daddy's place'... so, maybe they've got kind of more a feeling that home is with us (3)

\section{To be in an Indispensable Relation}

The first period of joint physical custody was described as unstable and painful in relation to the former partner. Discussions about the best solution for the children were emotionally hard and often complicated by sorrow over the broken relationship, disagreements, financial problems, or unsolved conflicts. Difficult and sensitive discussions, crucial for each individual's future was revealed. For example, disagreement regarding most optimal residential time, which's responsible for financing and purchasing clothes, who's responsible for covering up financially for the child or what went wrong in the couple relation.

\begin{abstract}
We had very different opinions about our relationship. It had been a really bad relationship for a long time, so I was kind of already on my way, but he didn't see it that way, so he had to talk and discuss and understand what went wrong and... (3)
\end{abstract}

Parents reported that they and their former partner mostly got along well during the decision phase of the joint physical custody. Even though different experiences were described; Communication, flexibility, and mutual support were described as the most prominent elements of a satisfying situation.

Both of us thought it was a very good idea because we really wanted to separate. It worked really well even from the very beginning. We have really good communication (5)

I think quarrelling in front of the children - I think that is very important to try to avoid, so the children don't have to feel torn between their father and mother, they kind of can love both of them (25)

As the children grew older, the contact with the former partner was described as rare. The children now managed the contact by themselves to an increasing extent. Nevertheless, importance of maintained contact over the child's teenage period and further in life, was described. Parents described their bonds to their former partners as life-long and important, for the sake of the child.

Like regular parents who can talk to each other at the dinner table, you need to call the other parent and check things out. Do you know where they are? Yes, check it out (12)

The parent role is forever, and you will have to maintain it your entire life. You still must be able to communicate and have a relationship, but on a different level (3)

\section{To Move Forward with Help from a Third Party}

There were descriptions of how they got stuck in unsolvable situations with their former partners, e.g. making contracts for leaving and retrieving routines, money issues, and allocation of holidays. Approximately one third chose to get help from the society. Descriptions of no parental contact or communication at all, disagreement of leaving and retrieving routines which in turn resulted in longstanding conflicts, and who's responsible for paying different sorts of child bills were the most common issues exposed.

\section{...kind of too much, too uncomfortable, then. Then I thought it was a proper way to deal with it, to contact the family counselling then. Because the children get hurt in conflicts like this (10)}

Those who had established contact with municipal family counselling or family court expressed satisfaction with the help they received, and considered it better to seek help instead of quarrelling and continue to hurt each other and the children. The conflict was described as turning into more neutralized when a third party were involved. They exposed that they were helped to understand the usefulness of cooperative co-parenting and how to avoid unnecessary conflicts. Voluntary municipal family counselling was suggested, in order to prevent unsolvable conflicts for the individuals involved, especially the children.

The kids felt bad when their parents argued and quarrelled so we tried to do the best we could, to get help and solve our problems and try to cope in a better way (10)

\section{DISCUSSION}

This qualitative study provides insights into parent's experiences of living in joint physical custody with their children. The participants reported many positive experiences, and a similar process of adapting to the new arrangement. In the initial period, the parents seemed mainly to have been occupied with emotional reactions to the new family situation. After two to three years, or longer in some cases, things seemed to settle down and the participants became more comfortable with and accustomed to the joint custody arrangement. When interpreting our results, it must be noted that the participants experienced different lengths of time since their families where reconstructed. It is also important to remember that our results reveal the parents' opinions only; we do not have the opinions of their children.

While participants in various ways learned to deal with the family situation, their feelings of emptiness when living without their children still remained. This is consistent with Amato's [39] divorce-stress-adjustment perspective drawn from family systems theory. A family is a complex, multilateral, and interdependent system, in which the action of one member may be expected to have an impact on the others [40]. In the initial period of joint physical custody, when parents are highly occupied with their own concerns, emotions, and moves, the stressful event of the separation might lead to further consequences for the entire family.

The first period, was described as the most challenging to deal with. The parents illustrated how their children felt like furniture, moved around between parents, even though the 
distance wasn't very far. This in turn made the parents feel like harming their children. Smart [41] as well as Haugen [42] illustrated how joint custody may cause problems for children who feel they have no logical arguments to oppose the arrangement. The children therefore adopt the adults' decision without arguing. Similar to earlier studies on children in different family structures, our participants described their children as satisfied and doing well in the new situation $[28,29]$. In line with Stafford-Markham and Coleman, the interviews revealed that unresolved conflicts i.e. economic issues, holiday planning or leaving and retrieving routines complicated the relationship with the former partner [43]. Bauserman [29], showed that parents with joint physical custody reported less conflicts compared to reconstituted families. Also, in a quantitative crosssectional study with 4959 school children aged 11.5 to 15.5 years, Levin and Currie [31] confirmed that communication within the family predicted better health and well-being for families included.

The analysis show that the participants appreciate and strive for functional family relations, which possibly can be seen as families living in joint physical custody are still families. Consistent with a family systems perspective, the individuals have considerable influence on each other as the family adjusts to the new situation $[44,45]$. The parts of the family system are linked in a mutual interaction in which every part affects the others $[46,47]$. For a family system to continue to function after a separation, it is important that members, especially parents, continue to cooperate [46-48]. Nevertheless, family studies show diverse results, so further studies will be needed before consensus can be reached regarding the desirability of joint physical custody.

A number of publications indicate that families who function better prior to the separation benefit more from joint custody compared to high conflicted families [9, 19, 35]. However, recently conflicting results have been shown [49]. Joint physical custody is supposed to be decided upon and arranged by the parents for the good of the child $[19,31,50]$. If the parents cannot agree, courts may impose the terms of joint physical custody, in which case neither the children nor the parents choose the outcome. The child might be obliged by the court to stay at one parent's house and have limited contact with the other parent, or to stay in joint custody [26, 27]. As our results show, parents described it as a good option to seek help from the community, instead of going to court.

A qualitative method with content analysis was chosen to gain knowledge about parent's experiences of joint physical custody, given that joint physical custody still is rather uncommon patterns and commonalities were sought [36]. By including a broad range of participants with various experiences the possibility to gain valuable insights increases i.e. several schools in different areas of the community. In that way the likelihood of incorporating parents of different gender, ethnicities, socioeconomic background, and experiences was assessed as likely. The participants reported many similar experiences, but also diverse detailed descriptions of different solutions that made the joint physical custody solution work in their particular family. According to Polit and Beck [38], incorporating different types of participants in this way increases the chance of shedding light on the research question from a variety of perspectives.

The authors are aware of the significant limitations in the study. These include the small, non-random, sample, the lack of a comparison group of parents without joint physical custody, the reliance on self-report without objective outcome measures, and the lack of statistical analyses. This study is best regarded as a preliminary study that provides important hypotheses to be investigated with larger samples and more systematic and validated measures.

The participants were self-selected into the study by responding directly to the first author when receiving the invitation letter. Those who chose to participate may have been those most influenced, negatively or positively, by their experience of joint physical custody, and therefore with the most committed interest in, and opinions about, the topic. There were limitations in the requiring procedure as there was narrow information regarding living arrangement in the study record, it is possible that advertising had given a different number of participants. The strong and reflective narratives (on average 50 minutes) revealed valuable and important information about parents' experiences of joint physical custody. In conclusion, joint physical custody is a complex construct. Until effective interventions for children and parents are readily available, our challenges in facilitating life for separated families will continue. Municipal family counselling was shown to help parents realise beneficial effects of cooperative co-parenting and avoidance of conflict. Many participants suggested voluntary municipal family counselling as a useful tool for separating parents. This advice could have implications for public health policy.

To advance the understanding of joint physical custody, additional studies are needed, to investigate the impact of joint physical custody on family members. Qualitative longitudinal studies regarding joint physical custody should be undertaken among parents and children, due to the fact that joint physical custody and family health is a common and relatively unstudied occurrence.

\section{CONFLICT OF INTEREST}

The authors confirm that this article content has no conflict of interest.

\section{ACKNOWLEDGEMENTS}

Declared none.

\section{REFERENCES}

[1] Statistics Sweden. Children, parents and separations. Stockholm 2013.

[2] Gähler M, Hong Y, Bernhardt E. Parental divorce and union disruption among young adults in Sweden. Stockholm: Stockholms Universitet 2009.

[3] Brolin- Låftman S. Children's living conditions: Studies on health, family and school. Disertation: Swedish Institute of Social Reseach 2009.

[4] McBroom LA. Understanding postdivorce coparenting families: integrative literature review. J Am Acad Nurse Pract 2011; 23(7): $382-8$.

[5] Gunnoe ML, Braver SL. The effects of joint legal custody on mothers, fathers, and children controlling for factors that predispose a sole maternal versus joint legal award. Law Hum Behav 2001; 25(1): 25-43. 
[6] Amato P. The impact of family formation change on the cognitive, social, and emotional well-being of the next generation. Future Child 2005; 15(2): 75-96.

[7] Amato P, Meyers C. Changes in nonresistent father child contact from 1976 to 2002. Family Relat 2009; 58: 41-53.

[8] Fabricius WV, Luecken LJ. Postdivorce living arrangements, parent conflict, and long-term physical health correlates for children of divorce. J Fam Psychol 2007; 21(2): 195-205.

[9] Kelly JB. Children's living arrangements following separation and divorce: Insights from empirical and clinical research. Fam Process 2006; 46(1): 35-52.

[10] Ringbäck- Weitoft G, Hjern A, Haglund B, Rosèn M. Mortality, severe morbidity, and injury in children living with single parents in Sweden: a population- based study. The Lancet 2003; 361: 28995.

[11] Madden-Derdich DA, Leonard SA. Shared Experiences, Unique realities: formerly married mothers' and fathers' perceptions of parenting and custody after divorce. Family Relat 2002; 51(1): 3745.

[12] Parkinson P, Cashmore J, Single J. Adolescents views on the fairness of parenting and financial arrangements after separation. Family Court Rev 2005; 43(3): 430-45.

[13] Cashmore J, Parkinson P. Parenting arrangements for young children: messages from research. Aus J Family Law 2011; 25(3): 236-57.

[14] Breivik K, Olweus D. Children of divorce in a Scandinavian welfare state: Are they less affected than US children? Scand J Psychol 2006; 47(1): 61-74.

[15] Bastaits K, Ponnet K, Mortelmans D. Parenting of divorced fathers and the association with children's self-esteem. J Youth Adolesc 2012; 41(12): 1643-56.

[16] Scharte M, Bolte G. Increased health risks of children with single mothers: the impact of socio-economic and environmental factors. Eur J Public Health 2013; 23(3): 469-75.

[17] Pagani LS, Japel C, Vaillancourt T, Cotè S, Tremblay E. Links between life course trajectories of family dysfunction and anxiety during middle childhood. J Abnormal Child Psycol 2008; 36: 4153.

[18] Jablonska B, Lindberg L. Risk behaviours, victimisation and mental distress among adolecents in different family structures. Soc psychiatry pshchiatr Epidemiol 2007; 42: 656-63.

[19] Amato P, Kane JB, James S. Reconsidering the "Good Divorce". Fam Relat 2011; 60(5): 511-24

[20] Statistics Sweden. Children of today- A description of children's conditions based on CRC (In Swedish)Barn i dag- En beskrivning av barns villkor med Barnkonventionen som utgångspunkt: Statistics Sweden 2009

[21] King V, Sobolewski JM. Nonresident fathers' contributions to adolescent well-being. J Marriage Family 2006; 68(3): 537-57.

[22] Kalmijn M, Loeve A, Manting D. Income dynamics in couples and the dissolution of marriage and cohabitation. Demography 2007; 44(1): 159-79.

[23] Teachman JD. Stability across cohorts in divorce risk factors. Demography 2002; 39(2): 331-51.

[24] Kalmijn M. Explaining cross- national differences, in marriage, cohabitation, and divorce in europe, 1990-2000. Populat Stud 2007; 61(3): 243-63.

[25] Statistics Sweden. Tables over Swedish population. (In Swedish) Tabeller över Sveriges befolkning 2010.

[26] Statistics Sweden. Cohabiting, children, married, separated? Pairing and separations among first time parents (In Swedish) Sambo, barn, gift, isär? Parbildning och separationer bland förstagångsföräldrar Stockholm: Statistics Sweden Report No: 1654-510, 2012.
[27] Ministry of Justice. The parental Code (In Swedish) Föräldrabalk 2010; 2010: 1204 .

[28] Bjarnason T, Bendtsen P, Arnarsson AM, et al. Life satisfaction among children in different family structures: A comparative study of 36 Western societies. Child Soc 2010; 26(1): 51-62.

[29] Bauserman R. Child adjustment in joint-custody versus solecustody arrangements: a meta-analytic review. J Fam Psychol 2002; 16(1): 91-102

[30] Carlsund Å, Eriksson U, Löfstedt P, Sellstrom E. Risk behaviors in Swedish adolescents; is shared physical custody after divorce a risk- or a protective factor? Eur J Public Health 2011; doi: 10.1093/eurpub/cks011

[31] Levin, Currie C. Family structure, mother- child communication, father- child communication, and adolescent life satisfaction. Health Educ 2010; 110(3): 152-68.

[32] Dunlop R, Burns A, Bermingham S. Parent- child relations and adolecent self- image following divorce: A 10 year study. J Youth Adolecence 2001; 30(2): 117-34.

[33] Ackard DM, Neumark- Sztainer D, Story M, Perry C. Parent- child connectedness and behavioral and emotional health among adolecents. Am J Prev Med 2006; 30(1): 59- 66.

[34] Schulte IE, Petermann F. Familial risk factors for the development of somatoform symptoms and disorders in children and adolescents: a systematic review. Child Psychiat Hum Dev 2011; 42 569-83.

[35] Kelly JB, Emery RE. Children's adjustment following divorce: Risk and resilence perspectives. Family Relat 2003; 52: 352-62.

[36] Patton M. Qualitative reseach \& evaluation methods. London: Sage Publications 2002

[37] Graneheim UH, Lundman B. Qualitative content analysis in nursing research: concepts, procedures and measures to achieve trustworthiness. Nurse Educ Today 2004; 24(2): 105-12.

[38] Polit DF, Beck CT. Nursing Research: Generating and Assessing Evidence for Nursing Practice. Philadelphia: Lippincot Williams \& Wilkins 2012.

[39] Amato P. The consequences of divorce for adults and children. J Marriage Family 2000; 62(4): 1269-87.

[40] Minuchin S. Families and family therapy. Cambridges: Harvard University Press 1974

[41] Smart C. Equal shares; right's for fathers or recognition for children? Crit Social Policy 2004; 24: 484-503.

[42] Haugen G. Children's perspectives on everyday experiences of shared residence: time, emotions and agency dilemmas. Child Society 2010; 24: 112-22.

[43] Stafford-Markham M, Coleman M. The god, the bad, and the ugly: divorced mothers experiences with coparenting. Family Relat 2012; 61(14): 586-600.

[44] Bowen M. Family therapy in clinical practice. Oxford: Rowman Littlefield Publishers 1978.

[45] Crittenden PM, Dallos R. All in the family: integrating attachment and family systems theories. Clin Child Psychol Psychiat 2009; 14(3): 389-409.

[46] Riley Sagar R. Bowen theory \& practice Georgetown: Georgetown Family Center 1997.

[47] Bowen M. Theory in the practice of psychotherapy. Guerin PJ. ed. New Yourk: Gardner 1976.

[48] Kerr M, Bowen M. Family evaluation: an approach based on Bowen theory. New York: W. W. Norton \& Company 1988.

[49] Nielsen L. Shared residential custody: a recent research review (pt. 1). Am J Fam Law; 2013 27: 61-72.

[50] Leon K. Risk and protective factors in young children's adjustment to parental divorce: A review of the research. Fam Relations 2003; 52: $258-70$

This is an open access article licensed under the terms of the Creative Commons Attribution Non-Commercial License (http://creativecommons.org/licenses/ by-nc/3.0/) which permits unrestricted, non-commercial use, distribution and reproduction in any medium, provided the work is properly cited. 